\title{
"The Hagiography of a Secular Saint: Alexander von Humboldt and the Scientism of the German Democratic Republic"
}

\author{
Dr. James F. Howell, Ph.D. - University of Arizona
}

\section{Introduction}

Twenty-seven years after the fall of the Berlin Wall and the collapse of Eastern European communism, eastern Germany remains the most secular region on the planet. Out of the forty-six countries and regions investigated by the World Values Survey, eastern Germany had, at 25.4\%, more than twice the number of self-declared atheists than the next closest country, Japan (Froese and Pfaff 397-398). And with the percentage of its residents not believing in god remaining at nearly $70 \%$, eastern Germany has proven resistant to the religious resurgence experienced by other nations in the former Soviet Bloc (400). The reasons for such a culture of secularism are, of course, manifold; chief among them, however, is the lasting impact of the wissenschaftliche Weltanschauung sponsored by the ruling Sozialistische Einheitspartei Deutschlands (SED) in the former German Democratic Republic (GDR). Although such official programs of secularization existed in some form or another in each of the former Soviet satellite states, the GDR's promotion of a Marxist-Leninist materialist worldview proves to be the most resilient, as evidenced by the World Values Survey.

At the heart of East Germany's implementation of its wissenschaftliche Weltanschauung was a program of substitution, a program that provided the population with the option of replacing formerly held religious beliefs with a more contextually appropriate Marxist-Leninist alternative. Alexander von Humboldt, among other luminaries from Germany's past such as Johann Wolfgang Goethe and Georg Forster, proved essential to this substitution by providing the SED with a face and historical weight to accompany the state-sponsored secular philosophy. East German authors and politicians recruited and reimagined Humboldt as a socialist scientist and a champion of the oppressed in order to provide scientific and cultural legitimacy to the state's official ideology and political agenda. The following analysis explores how the East German cultural apparatus supported the SED's systematic propagation of its wissenschaftliche Weltanschauung in part by representing and using historical actors like Alexander von Humboldt as substitutes for traditional religious figures and their respective social functions. Such an investigation, in turn, elucidates the inception of a secularist cultural tradition that continues to influence and shape eastern German culture up to the present day.

\section{Scientism in the GDR}

In order to cement its power culturally as well as politically, the SED sought early on in its existence to challenge the authority practiced, and the metaphysical worldview espoused by the religious denominations active in the GDR. This challenge took shape in two distinct forms. The first, which will be addressed in more detail later on, was the direct political persecution and expropriation of religious organizations. The second was to offer an opposing materialist worldview that would compete with traditional religious doctrines. This new worldview rested on the conviction that the scientific method yielded the most reliable access to the truth, and that science provided "the only path to a glorious future" (Schmidt-Lux, "Science as Religion" 28). The wissenschaftliche Weltanschauung promoted by the SED, however, proves difficult to 
define with any degree of specificity, due the ubiquity and the reflexivity of its use. Indeed, the "term Wissenschaftliche Weltanschauung [...] could be found in almost any official GDR document" (20). Despite the vagueness that often accompanied its use in East German texts, the term wissenschaftliche Weltanschauung bespoke the fundamental principles of MarxismLeninism and encompassed

\begin{abstract}
die Trias aus dialektischem und historischem Materialismus, politischer Ökonomie sowie wissenschaftlichem Sozialismus bzw. Kommunismus. Gleichzeitig fand [der Begriff] aber auf eine Weise Verwendung, die ihn - zusätzlich zur formalen Definition - als eine Art Metakategorie bzw. Chiffre auswies. Mit der Rede von der wissenschaftlichen Weltanschauung wurde auf grundsätzliche Prämisse verwiesen, die einerseits für den Marxismus-Leninismus Gültigkeit besaßen, gleichzeitig jedoch allumfassend gesellschaftlich wie individuell maßgeblich sein sollten. (Schmidt-Lux, „Das helle Licht der Wissenschaft" 57)
\end{abstract}

Although a scientific worldview might seem a predictable outcome or consequence of the implementation of a broader Marxist-Leninist ideology at a national level, its discursive presence and dominance represent no mere coincidence; rather, the institution of the wissenschaftliche Weltanschauung at every level of GDR society must be understood as an instrument "of a general process of disenchantment, a process that did not just occur, but was initiated on purpose" (Wohlrab-Sahr, Schmidt-Lux, and Karstein 130).

At its core, the wissenschaftliche Weltanschauung promoted by the SED exemplifies a scientistic ideology, an ideology that not only seeks to utilize science as a means to find answers, but that also considers science itself as an answer to fundamental questions. In the East German context, scientism stood for an understanding of reality that „Wissenschaft zum obersten Prinzip allen Denkens und Handelns erhob und ihren Geltungsanspruch auf die gesamte Gesellschaft ausdehnte“ (Schmidt-Lux, „Das helle Licht der Wissenschaft“ 44). This conceptualization of science not only ran implicitly contrary to the doctrines of the Catholic and Evangelical Churches by offering a competing source of knowledge and means of understanding; instead, the manifestations of scientism in the GDR took on an actively anti-religious or explicitly condescending tone when addressing competing or conflicting worldviews. The East German cultural apparatus cast its narratives concerning the power of human reason and the limitless reach of human progress in direct opposition to any metaphysical framework. This opposition centered itself on the belief that such a

Wissenschaftsverständnis legte Konflikte mit religiösen Akteuren [...] nahe, weil sich Wissenschaft nicht mehr allein für die beobachtbaren und erfassbaren Bereiche der Welt zuständig sah, sondern vielmehr konkurrierender ,Angebote innerweltlicher Erlösung، [...] offerierte. Wissenschaft wurde damit auch für ,letzte Fragen' zuständig erklärt und weitete ihren Geltungsbereich auf Sphären aus, die gemeinhin Religion für sich beanspruchte [...]. (45)

The worldview crafted and propagated by the SED sought not only to negate religious doctrine with its rejection of the metaphysical; rather, this scientistic philosophy produced its own rubric of explanation, as well as an ethical code that stood in direct competition with that of the JudeoChristian tradition. In 1958, for instance, Walter Ulbricht, the First Secretary of the Central Committee of the SED from 1950 to 1971, presented East Germany with the "10 Commandments of Socialist Morality." This explicit appropriation of a framework from a well- 
known religious value system helped to highlight the supposed ethical foundation of the socialist East German state; while at the same time such an ideological duplication "helped legitimize a person's decision to renounce church membership" (Wohlrab-Sahr, Schmidt-Lux, and Karstein 135). And to be sure, "Church membership and party membership were treated as mutually exclusive" (133).

The ways in which the East German political establishment pursued its scientistic agenda by promoting a wissenschaftliche Weltanschauung can be divided into two distinct periods. The first period of this anti-religious activity was characterized by direct political confrontations initiated by the state's targeting of various denominations, primarily the Catholic and Evangelical Churches. Although the drafters of the GDR's constitution and judicial framework had created on paper an ideologically progressive environment, in which religious organizations received guarantees of legal protection, such guarantees rarely materialized in practice. During "the period that saw the stabilization of the state system and entrenchment of single-party rule," the SED "did not [...] feel particularly constrained by the constitution" (Peperkamp and Rajtar 6 ), and the treatment of religious institutions became increasingly and openly hostile. In coordination with directives and campaigns originating in the USSR and other Soviet Bloc states, the East German government initiated in 1952 a set of policies that eventually became known as the Kirchenkampf (harkening back to the National Socialist programs of the same name), in which "religious education was suppressed, the Christian youth movements dissolved, and many religious organizations and charities abolished" (Froese and Pfaff 406). The SED had planned to continue its highly aggressive and internationally controversial campaign beyond 1953, but „[d]ie nach dem Tod Stalins gebildete neue sowjetische Führung verhinderte die Fortführung des „Kirchenkampfes“ in der DDR“ (Wentker 122). Even though the relatively short lived Kirchenkampf resulted in the widespread dispossession of church property and the dramatic weakening of religious institutions within the GDR, it did not precipitate the decrease in church membership desired by the SED.

Following the premature cessation of the Kirchenkampf in 1953 began the second, and much more effective, phase of the GDR's implementation of a scientistic alternative to traditional religious practice. This period, from 1954 to 1990, witnessed a less direct and confrontational strategy on the part of the SED regarding its propagation of the wissenschaftliche Weltanschauung. As opposed to the explicitly hostile environment of the Kirchenkampf, the East German cultural apparatus began a subversive campaign of substitution that would eventually affect almost every aspect of society within the GDR. Oftentimes this substitution took the form of reproducing Christian practices in a secular, socialist, and scientistic manner. In 1954, for example, the SED strongly recommended that all 14-year-olds throughout the country prepare for and celebrate the so-called Jugendweihe (Froese and Pfaff 407). Although prior to this period an entirely voluntary ceremony practiced by the children of party members, the Jugendweihe directly undermined Evangelical Church authority in East Germany, as it represented "a secular coming-of-age ceremony that was intended not only to compete with, but also to substitute for, Protestant confirmation" (Wohlrab-Sahr, Schmidt-Lux, and Karstein 130). With the pervasive preparation for the Jugendweihe, which nakedly propagated the socialist wissenschaftliche Weltanschauung, the process of confirmation in a religious organization became seemingly redundant. Practicality and social mobility also influenced the increasing amount of cultural value that accompanied the Jugendweihe, owing to the fact that the "ceremony became a de facto requirement of access to good jobs and educational opportunities, especially the school-leaving certificate required for higher education" (Froese and Pfaff 407). The dramatic effect exercised 
by the Jugendweihe in the East German program of secular and scientistic substitution reveals itself in the fact that by the 1980s, participation in the ceremony had reached rates as high as ninety-seven percent, whereas only approximately one-fifth of the children in the country were confirmed in any religion (407).

The educational system constituted another realm of East German social and cultural life affected by the less confrontational strategies initiated by the SED to subvert religious authority and advance its scientistic worldview following the more aggressive years of the Kirchenkampf. Schools in the GDR promoted and fostered courses in the physical and natural sciences while engaging in ,die schrittweise Verdrängung des Religionsunterrichts“ (Schmidt-Lux, „Das helle Licht der Wissenschaft" 59). The undermining of religion and its attendant frameworks of knowledge occurred either implicitly or explicitly in every instructional setting in the GDR, regardless of the subject matter or the level of the students. The SED mobilized the educational infrastructure of East Germany in order that "in the classrooms, students at schools and universities were compelled to join the struggle against religious beliefs and worldviews" (Froese and Pfaff 407). Children in school, however, did not make up the only educational audience for the SED's scientistic message, as instruction in the wissenschaftliche Weltanschauung carried over into adulthood in the context of „Arbeiter- und Bauernfakultäten und andere Bildungseinrichtungen“ (Schmidt-Lux, „Das helle Licht der Wissenschaft“ 58).

The SED also focused a great deal of organizational effort and financial resources on the sphere of popular culture in order to promote and implement its wissenschaftliche Weltanschauung more broadly. Urania: Gesellschaft zur Verbreitung wissenschaftlicher Kenntnisse represents perhaps the most concerted attempt by the East German cultural apparatus to charge popular discourses with scientistic themes as well as provide the public with a materialist perspective firmly rooted in the wissenschaftliche Weltanschauung. Urania engaged the people of East Germany in a number of ways. It hosted lectures, maintained a presence on radio and televisions channels with regular programs and broadcasts, and published books and journals from its own publishing house, the Urania Verlag. And "with branches in nearly every town in East Germany" (Schmidt-Lux, "Science as Religion” 27), Urania's reach encompassed virtually the entire population of the country. The stated mission of the organization consisted of transmitting scientific knowledge to the nation at large. This transmission, however, also served a dual purpose by providing the East German government with a vehicle for its scientistic worldview; and through organizations such as Urania ,wurde offizielle Ideologie in gewisser Weise übersetzt und eben popularisiert und darüber anschlussfähig gemacht für Personen außerhalb des staatsnahen oder akademischen Umfeldes“ (Schmidt-Lux, „Das helle Licht der Wissenschaft" 71). Urania also represented the cultural and financial dominance of the SED over religious organizations, as none of the denominations could subsidize their message to the same extent as the state-funded organs. Although Urania did collect money through membership and entry fees, it received the vast majority of its funding „durch staatliche Zuschüsse“ (61). The ambit of Urania's activities far exceeded that of religious organizations as well. By the mid1970s, for instance, Urania's lecture series alone consisted of over 350,000 events per year with an annual attendance of almost twelve million, numbers that would remain at approximately the same levels until the dissolution of the East German state (61).

Scientific lectures like those sponsored and presented by the Urania society were so common that the East German cultural establishment prepared materials for potential speakers, such as a 
brochure that contained, among other things, advice about how to deliver public lectures on [Alexander von] Humboldt 'in a manner that corresponds to the needs an requirements of our time'. One of the suggestions was to present Humboldt in the context of an anthology of writings by Marx, Engels, Lenin and Stalin [...]. (Rupke 111-112)

This example not only demonstrates that Humboldt constituted an important element within the promotion of the wissenschaftliche Weltanschauung, but also makes clear that East German institutions concerned themselves greatly with the specific thematization of figures such as Humboldt. Indeed, the mission of organizations like Urania consisted in identifying and defining "the limits of 'legitimate knowledge' within the GDR" (Schmidt-Lux, "Science as Religion" 31).

\section{Humboldt in GDR Culture}

As a means of furthering the state-sponsored wissenschaftliche Weltanschauung, East German cultural institutions began a process of reinterpreting and rehabilitating certain key figures from Germany's history. These figures, in turn, provided the socialist and scientistic ideology of the GDR with a means of identification and points of reference that connected the culture's proud past to the bold new future promised by the SED. The bulk of these historical personae consisted of progressive artists, radical liberal politicians, and scientists, such as Heinrich Heine, Georg Forster, and Ernst Haeckel. In this intellectual environment, Alexander von Humboldt presented the East German cultural apparatus with the ideal embodiment of its materialist worldview, owing to the fact that he combined a formidable scientific legacy with a reputation as an outspoken cosmopolitan. As with many celebrated members of the German cultural canon, however, East German authors and politicians often exaggerated Humboldt's liberal and progressive credentials to the limits of credulity. These writers and political figures proffered a representation of Humboldt thoroughly colored by the socialist context; and, to be sure, of "the manifold geographic-temporal spaces in which a particular Humboldt was constructed, that of the GDR was the most distinct" (Rupke 105). As the East German interest in Humboldt intensified, authors and other cultural actors sought out any possible link that they could find between the Prussian baron and the newly established socialist state of workers and farmers. Many in East Germany, for instance, expressed great pride in the fact that the one-hundredth anniversary of Humboldt's death occurred in the same year as the GDR's tenth anniversary, and that the two-hundredth anniversary of Humboldt's birth took place during the nation's twentieth anniversary. For many writers, these temporal connections did not constitute mere coincidence; and neither did the fact that the main building of the Akademie der Wissenschaften der DDR stood on the same ground as Humboldt's birthplace, or that the headquarters of the Henscheverlag Kunst und Gesellschaft occupied the same site as Humboldt's final residence. For Kurt-Reinhard Biermann, a longtime member of the research arm of the Akademie der Wissenschaften, such a spatial connection encapsulated ,die innige, in der Gegenwart wirkende und in die Zukunft weisende Bindung an das verpflichtende Erbe Alexander von Humboldts“ within GDR culture (Alexander von Humboldt 9).

The celebration of Humboldt's legacy pervaded every level of East German cultural life. In 1959, as a means to recognize outstanding contributions to science and humanity, the Akademie der Wissenschaften created the Humboldt Medal. The Akademie conferred one of the first two Humboldt Medals it minted to Walter Ulbricht, indicating the significance and prestige the award enjoyed (Rupke 111). In the same year, targeting a much younger and less socially 
elite audience, Theo Piana and Horst Schönfelder published a comic book thematizing Humboldt's life, explorations, and scientific work entitled Alexander von Humboldt: Ein deutscher Weltreisender und Naturforscher. This richly illustrated volume portrays Humboldt as a hero of the common man, toiling alongside proletarian miners in his youth, and in old age as a fast friend of the Russian people who feels young again once in their midst. In 1989, the first GDR-FRG coproduced film, Die Besteigung des Chimborazo, allowed German audiences of all ages and backgrounds the opportunity to share cinematically in one of Humboldt's most adventurous and famous feats, the near-summiting of the volcano Chimborazo in today's Ecuador (Schäfer 7). These examples not only illustrate the multimediality of Humboldt representation in East Germany, they also demonstrate that interest in, and engagement with Humboldt spanned the entire life of the GDR.

Even though the study of Humboldt reception in East Germany proves possible in any number of media, the following part of this analysis focuses on the textual representation and use of the scientist-explorer by biographers and authors writing for both scholarly and popular audiences in the GDR and other Second World nations. The subsequent textual examples elucidate the ways in which the East German cultural establishment, with the faculties of its universities and research institutes at the forefront, enlisted Humboldt in the promotion of the scientistic worldview that rested at the heart of the nation's socialist ideology. Although Humboldt scholarship in the GDR should not be misunderstood as overly monolithic and dictated in every detail by political functionaries, as demonstrated definitively by Gregor Schuchardt in his authoritative study of East German Humboldt research Fakt, Ideologie, System, certain representational motifs consistently appear that support the overall Marxist-Leninist recontextualization of Humboldt and his legacy. And as previously mentioned, such recontextualization and subversion through substitution constituted the core of the campaign to advance the conceptual framework of the wissenschaftliche Weltanschauung. In much the same way as the SED had replaced religious confirmation with the secular Jugendweihe, East German writers and scholars attempted to replace the reverence afforded traditional religious personages with the glorification of a host of heroes from Germany's past. In the vanguard of these supposed champions of socialism stood Alexander von Humboldt.

In order to understand better this process of retroactive socialist glorification, an initial, detailed investigation of the diction surrounding textual Humboldt representation proves invaluable. Such an analysis notably reveals that even though the wissenschaftiche Weltanschauung of the GDR and its scholarly community espoused diametric opposition to traditional religious philosophy and what they understood as its opiate effects on society as a whole, a certain amount of metaphysical, and in certain cases specifically Christian, terminology emerges in East German Humboldt texts. Historian of science Gerhard Harig, for instance, defends the broad scope of Humboldt's scientific interests, and warns against the attempts of any one scholarly field to lay exclusive claim to his legacy. This restricted reading and use of Humboldt, cautions Harig, would risk the destruction of the „Zauber der Humboldtschen Schriften" (Vorwort 6). Werner Hartke, a philologist and the rector of the Humboldt University in the late 1950s, speaks of Humboldt's „Prophezeiung“ regarding the discovery of diamonds in the Ural Mountains (xii); and Manfred Kossok, historian of Latin America, likewise regards Humboldt's predictions regarding the independence of colonial Latin America as ,prophetisch“ (18). In addition to this oracular characterization, one-time minister of culture in the GDR Alexander Abusch summons up the past in the present by asserting that ,[d]ieser Mann, Alexander von Humboldt, und unsere deutsche sozialistische Republik - sie sind miteinander 
verbunden in einer großen geschichtlichen und geistigen Kontinuität“(,Alexander von Humboldt" 15). And while discussing the influence Humboldt exercised on Prussian higher education, Heinz Sanke, another former rector of the Humboldt University in East Berlin, describes Humboldt's belief in, and advocacy of the „Trinität von Bildung, Erziehung und Forschung" (,Alexander von Humboldt" 57). The appearance of such metaphysical language, while limited in East German texts, indicates the level of reverence these writers wished to project upon Humboldt and his reinvented legacy.

The language of scientism and Marxism-Leninism, however, pervades Humboldt texts and constitutes a much more important discursive theme than any explicit use of metaphysical or theological terminology. Scholars and writers used this scientistic and socialist language to distinguish Humboldt from most of his peers and to align him with the tradition and continuity of Marxist-Leninist thought. Titles such as „Dialektiker,“ „Humanist,“ and „Realist“ highlighted Humboldt's focus on the material and the empirically provable when investigating natural and social phenomena. When compared with his contemporaries, Humboldt's ideas and intellectual frameworks often proved more advanced and forward thinking in the estimation of East German writers. Geographer Erwin Schmidt, for instance, compares Humboldt's understanding of the geographical sciences to Carl Ritter's, and finds Ritter's analyses wanting. Schmidt concludes

Ritters scheinbar klare dialektische Erkenntnis jedoch bekommt als Grundlage einen übernatürlichen Schöpfer. Diese Gegenüberstellung zeigt, daß Humboldt in diesem Punkt bereits der weitblickendere war. Seine naturwissenschaftlichen Erkenntnisse sind in ihrem Wesen materialistisch. Ritters scheinbare Dialektik hat dagegen eine mystische Basis. (91)

Perhaps the most ubiquitous label placed on Humboldt by East German scholars is that of „spontaner Materialist.“ Kurt-Reinhard Biermann, Johannes F. Gellert, and Heinz Sanke among others confer this title on Humboldt to situate him contextually within the timeline of the socialist historical narrative. These scholars identified Humboldt's materialism as spontaneous, owing to the fact that Humboldt developed it on his own, without the guiding light of the conceptual frameworks envisioned by Marx, Engels, and Lenin. Sanke, for instance, considers Humboldt's conceptual evolution in this regard a natural and obvious outcome, considering the nature of his scientific research and the discursive contexts in which he lived and worked:

Es waren die Erfordernisse und Notwendigkeiten der Naturforschung und des naturwissenschaftlichen Studiums, die ihn selbsttätig und zwangsläufig zum Materialismus und zur Dialektik führten[.] [...] Alexander von Humboldt war also spontaner Materialist, einmal aus seiner Arbeit heraus, zum anderen flossen ja bereits die Quellen, aus denen Karl Marx und Friedrich Engels später schöpfen sollten. [...] So brauchen wir uns gar nicht zu wundern, wenn wir bei Alexander von Humboldt eine Fülle von Gedankengängen und Verfahrensweisen - und sei es auch nur in den Anfängen - feststellen können, die wir bei den Klassikern des Marxismus-Leninismus vollendet finden. („Die gesellschaftlich-geographische Auffassung“ 60-61)

East German authors interpreted this sort of unshepherded revelation as proof of the depth of Humboldt's intellect and insights. In a rather counterintuitive way, the lack of reference to Marx in Humboldt's private and public writings testified to his socialist credentials. Several East German writers portray Marxist-Leninist philosophy as a kind of conceptual phantom haunting Humboldt's writings. Schmidt alludes to this uncanny sense of absence when he notes, ,[d]ie 
politisch-ökonomischen Gesetze als Treibfedern der gesellschaftlichen Entwicklung sind ihm unbekannt. Aber er ahnte sie, ohne ihnen einen Namen geben zu können" (90). And if he appeared occasionally to give into the idealism of his peers, Gellert assures his East German audience,

Alexander von Humboldt war seiner Geisteshaltung nach Humanist und Realist, ja in seinen wissenschaftlichen Betrachtungen sogar spontaner Materialist und Dialektiker, wenn auch - ein interessanter, aber deutlich spürbarer Widerspruch - seiner Zeit entsprechend, in durchaus idealistischen Gewand. (1-2)

In addition to his supposed materialism, Humboldt attested to his secular sainthood with his critical stance toward traditional religiosity and his own aristocratic class. Harig describes Humboldt's ambivalence as a „Kleinkrieg gegen Reaktion und Klerikalismus, dem er keineswegs aus dem Weg gegangen ist und den er mit Siegen und Niederlagen bis an sein Lebensende geführt hat" (,Alexander von Humboldt" 27). Although Humboldt did comment negatively on certain members of the clergy and the administration of church affairs in Prussia in certain private letters to Karl August Varnhagen von Ense that became at one point embarrassingly public, he never openly criticized European religious beliefs or practices. Herbert Scurla, however, ignores such nuance in his oft-reprinted biography of Humboldt, in which he asserts that „Humboldt wußte, daß seine Leistung mehr als eine nur wissenschaftliche Bedeutung hatte. Mit seinem naturwissenschaftlichen Weltbild zerstörte er den Mythos der biblischen Schöpfungsgeschichte; seine empirisch-kritische Weltanschauung rüttelte an einem der stärksten Fundamente der Reaktion" (325). Biermann also goes to great lengths to remove Humboldt from his aristocratic milieu in his essay „War Alexander von Humboldt ein ,Freiherr' (oder ,Baron“)?“ Biermann's evidence to the contrary is actually convincing, even if the analysis conspicuously fails to mention that Humboldt identified as a member of the aristocracy his entire life and consistently received the befitting respect and privileges thereof.

East German authors often cast Humboldt in the role of populist educator of the masses, drawing on his several attempts to make scientific research more accessible to the public at large. These writers presented their audience with a Humboldt who „sah die Naturwissenschaften nicht als Privileg einzelner Gruppen oder bevorzugter Schichten an, strebte vielmehr danach, sie zum Allgemeingut des ganzen Volkes, aller seiner Schichten und Klassen, zu machen“ (Sanke, „Alexander von Humboldt“ 59). In many East German narratives, Humboldt's zeal regarding informing the working class about the latest scientific advancements becomes interwoven with his supposed hostility toward church and state:

Alexander von Humboldt war dennoch ein Vorkämpfer der Humanität, grimmiger Feind der Reaktion, ein aufrechter Demokrat und ein bedeutender Pionier des Fortschrittes. Er bahnte der Naturwissenschaft den Weg, sicherte ihr die Gleichberechtigung neben den Geisteswissenschaften und vollstreckte das Erbe der Aufklärung, indem er die unwissenden, sich ihrer Unwissenheit bewußt gewordenen Menschen aus der von Staat und Kirche vorsätzlich konservierten Verdummung befreien half, sie gemeinverständlich belehrte und das Wissen um die Natur zu einer Macht erhob, deren die Menschheit bedurfte, um dem Ruf derer zu folgen, die sie aus der Versklavung befreien wollten. (Scurla 381)

This advocacy on behalf of the common person in many cases implicitly excused Humboldt's original sin of membership in Europe's aristocratic elite. Indeed, the fact that Humboldt „seinen 
Reichtum in einer Weise nutzte, die dem Fortschritt der Menschheit diente, gehört mit an erster Stelle zu den Taten, durch die er sich ein Denkmal in der Geschichte seines Volkes und der Menschheit gesetzt hat" (109).

East German audiences came across the characterization of Humboldt as sagacious teacher to the masses most often when reading about either a series of public events initiated in the late fall of 1827 that later became known as the Kosmos lectures, or the subsequent volumes published by Humboldt under the same title. The portrayal of the original lecture series in East German texts emphasizes the attraction exercised by Humboldt's persona and message. Gellert's depiction, for instance, conjures associations with a messianic figure delivering a type of Sermon on the Mount in the face of charges of heresy from jealous Pharisees:

Diese Vorträge erregten in ganz Deutschland größtes Aufsehen, richteten sie sich doch einerseits [...] gegen die spekulativen Naturlehre jener Zeit, was Alexander von Humboldt in ,Verruf ${ }^{*}$ eines Materialisten brachte, und suchten sie andererseits die immer tiefer werdende Kluft zwischen gelehrter Forschung und der Gedankenwelt der Gebildeten und Bildungswilligen $\mathrm{zu}$ überbrücken und $\mathrm{zu}$ beseitigen. Aus ganz Deutschland und aus dessen Nachbarländern kamen Gelehrte und Freunde der Naturwissenschaften nach Berlin, um Alexander von Humboldt zu hören, so daß der Vortragszyklus vor einem noch breiteren Publikum im größten Saal des damaligen Berlin, in der Singakademie, wiederholt werden mußte. (7)

For those not lucky enough to have taken in these secular teachings directly at the foot of the master, there still existed the possibility of absorbing Humboldt's message through the printed volumes of Kosmos: Entwurf einer physischen Weltbeschreibung. This ,revolutionäres und revolutionierendes Werk,“ argued East German writers, constituted a „Hebel für die Emanzipation der unterdrückten Massen“ (Sanke, „Die gesellschaftlich-geographische Auffassung“ 63). In this work, the great scientist-explorer's magnum opus, Humboldt ,stellte sein naturwissenschaftliches Weltbild dem herrschenden religiös-mystischen Weltbild gegenüber und trug dazu bei, die Gleichberechtigung der Naturwissenschaften gegenüber der Theologie und der idealistischen Philosophie zu erkämpfen“" (62-63).

East German writers did not exclusively restrict themselves to Humboldt's own actions and insights when casting him in the role of secular saint; instead, these authors readily fashioned those who followed in Humboldt's intellectual footsteps into figures reminiscent of apostles and martyrs. Abusch, for instance, makes extensive mention of Alfons Goldschmidt, an accomplished economist whom the National Socialist regime forced into exile and who died in Mexico in 1940. According to Abusch, this apostle deserves remembrance alongside Humboldt, because he faithfully spread Humboldt's legacy and ,träumte kämpfend von einer Zukunft, in der alle Völker in einer großen Brüderlichkeit verbunden sein werden, indem sie ihre materiellen und geistigen Leistungen ohne diskriminierende Bedingungen austauschen werden zu geistigem Nutzen“ („Alexander von Humboldt" 12). The geographer Alfred Rühl, on the other hand, died for his convictions at the hands of the National Socialists, and Sanke portrays him therefore as a martyr figure, whose Humboldtian convictions resulted in his execution:

Rühl machte sich das von Humboldt überkommende kulturelle und wissenschaftliche Erbe am umfassendsten $\mathrm{zu}$ eigen, übernahm dessen gesellschaftlich-geographische Grundkonzeption und entwickelte sie weiter. Er nahm unter den deutschen Geographen, die den Ideen und Idealen des Humanismus, des gesellschaftlichen Fortschrittes und der Wissenschaft auch im imperialistischen Stadium des Kapitalismus treu blieben und sich 
dem Faschismus nicht beugten, einen hervorragenden Platz ein. („Alexander von Humboldt" 67)

Even though both of these scholars suffered at the hands of the National Socialist state, Humboldt's legacy persevered and gained strength through adversity. Abusch, for instance, boasts pridefully that ,Selbst die Schmach, die Hitlers bestialischer Rassenwahn über Deutschland gebracht hatte, konnte - und das gilt bis auf den heutigen Tag - nichts daran ändern, daß Humboldts Ideen den sozialen und nationalen Befreiungskampf der Völker [...] durchdringen“ (,Alexander von Humboldt" 6).

Alongside these apostles and martyrs appear counterfeit and inaccurate representations of Humboldt, false prophets created by the "other" German state. As Abusch makes clear in his introduction to the volume Alexander von Humboldt: Wirkendes Vorbild für Fortschritt und Befreiung der Menschheit, these deformed West German fabrications constitute a perverse remainder from the Nazi era that promote a distorted image of Humboldt and his legacy:

Ja, wir kämpften zu jener Zeit gegen den Mißbrauch und die Verfälschung von Humboldts Namen und Geist, mit dem die deutsche faschistische Regierung ihre verbrecherische Politik zu tarnen versuchte. In der Gegenwart entspricht es dem Wesen des westdeutschen Staates, der die imperialistischen Traditionen Hitlerdeutschlands modernisiert weiterführt, daß er in seiner neokolonistischen Politik gegenüber den Völkern [...] weiterhin und zeitgemäß den Namen Alexander von Humboldts mißbraucht. (Zum Geleit viii)

Werner Hartke also chastises his West German counterparts for their duplicitous attempts to veil the rival nation's imperialist agenda behind the festivities surrounding the two-hundredth anniversary of Humboldt's birth. Hartke goes so far as to assert that the FRG used Humboldt and his anniversary celebrations as a venue to promote a Western chauvinistic program of German reunification:

Auch der andere deutsche Staat, die imperialistische westdeutsche Bundesrepublik, führt „Humboldt-Ehrungen“ durch, indem sie die gleisnerische, auf den ersten Blick unverbindlich und unanstößig erscheinende Behauptung propagiert, sie wolle das Gedächtnis Humboldts wachhalten und der jungen Generation einen Begriff von der universalen Bedeutung des großen deutschen Gelehrten vermitteln. In Wahrheit jedoch [...] werden handfeste politische Absichten verfolgt! Indem man in Westdeutschland bei der Universalität Humboldts stehen bleibt [...], verbirgt man dort hinter vorgetäuschter Humanität imperialistische Ziele und versucht, Humboldts Ansichten von einer Harmonie in der Natur demagogisch zu mißbrauchen. Man negiert die Existenz zweier deutscher Staaten mit diametral entgegengesetzter Grundposition. Man diskriminiert die sich immer stärker durchsetzende Bewegung zur Anerkennung der DDR als eines souveränen sozialistischen Staates. (xiii-xiv)

These East German accounts readily laid blame at the feet of the West German government for employing Humboldt as a political tool in its relations with Latin American countries. They all fail to mention, however, that the GDR had its own Latin American strategy that made extensive use of Humboldt and his legacy. Erich Honecker, the successor to Walter Ulbricht, for example, traveled twice to Latin America on official state visits, once to Cuba in 1974 and once to Mexico 
in 1981. On both of these occasions, "Humboldt was a common bond and [...] was utilized as a reason that friendship should reign between Latin America and East Germany" (Rupke 135).

East German writers not only linked Alexander von Humboldt to the socialist and communist tradition, but also attempted to designate the GDR as a city upon a hill and as such the legitimate heir to Humboldt's legacy. Heinz Sanke assuredly states that „,[e]s ist kein Zufall, daß das von Alexander von Humboldt überkommene wissenschaftliche und humanitäre Erbe seine Pflegestatt im ersten Arbeiter-und-Bauern-Staat der deutschen Geschichte, in der Deutschen Demokratischen Republik, gefunden hat“ („Die gesellschaftlich-geographische Auffassung“ 68). In identifying the GDR and its leadership as Humboldt's true progeny, East German authors such as Abusch also used Humboldt as a means to project the nation's best image of itself to the rest of the world:

Was Alexander von Humboldt vorgeahnt und vorgebildet hat, ein neues Deutschland der Humanität, wird in unserer Deutschen Demokratischen Republik verwirklicht [...]. Das lebenslange Wirken Humboldts gegen jede Art von Rassendiskriminierung, gegen jede Art von kolonialer Ausbeutung, für die Brüderlichkeit der Menschen aller Hautfarben, ist in unserem ersten sozialistischen Staat deutscher Nation zu neuer geschichtlicher Qualität entwickelt. Seine ethisch-moralischen Prinzipien sind zur Verfassungswirklichkeit in unserem Staat geworden. Unsere neue Gesellschaft ist die Schöpferin einer sozialistischen Kultur und Bildung für das ganze Volk ohne Klassen- und Standesschranken. So kann unsere Deutsche Demokratische Republik für sich in Anspruch nehmen, auch der legitime Erbe und Verwirklicher der edlen Ideen Alexander von Humboldts [...] zu sein. (,Alexander von Humboldt“" 13)

Alluding to a familiar, anti-Western theme, Abusch also contends that East Germany is the only nation of true believers, in which ,[d]ie Ideen Alexander von Humboldts wurden zur Macht des Lebens“ (Zum Geleit vii). Hartke echoes Abusch's assertion, remarking that „Nicht in Westdeutschland, sondern in der Deutschen Demokratischen Republik sind Humboldts bleibende Erkenntnisse, sein Vertrauen auf die Kraft, die in den Menschen steckt, wenn sie erst einmal zu denken begonnen haben - um mit Humboldt zu sprechen - Wirklichkeit geworden“" (xiv). As all of these selections demonstrate, the East German cultural establishment forcefully made the case to the world that there existed but one real Alexander von Humboldt, and the preservation of his legacy resided exclusively within the purview of the GDR.

Humboldt did not, however, represent the sole figure from the nation's past that received such attention from the East German cultural apparatus. Scholars and popular writers in the GDR recruited and rehabilitated dozens of historical personages in order to create a secular and scientistic pantheon of sorts. Indispensible members of the German canon, such as Johann Wolfgang Goethe and Friedrich Schiller, benefited from thorough and concerted programs of reinterpretation and reconfiguration, so as better to meet the needs and expectations of a MarxistLeninist society. In many instances, East German scholars employed Humboldt studies as an intellectual bridge, spanning the gap that separated idealistic and metaphysically minded artists and philosophers like Goethe from figures such as Karl Marx and Friedrich Engels. His supposed spontaneous materialism combined with his strong personal connection to the Weimarer Klassik positioned Humboldt as a model intermediary between fundamentally divergent intellectual traditions. Accordingly, Abusch presents Humboldt as chronologically well suited for such a task, asserting that ,[er] ideell in der Epoche zwischen dem Humanismus Johann Wolfgang 
Goethes und dem sozialistischen Humanismus von Karl Marx steht“ („Alexander von Humboldt" 9).

Although East German writers made great use of the connection between Humboldt and figures like Goethe, his relationship and intellectual affinity with Georg Forster represented the most common association with another recalibrated member of Germany's historical elite. In many East German texts, Forster serves to initiate Humboldt, to baptize him in the spirit of revolution and true science. The ideologically and politically liberal influence exercised by the older Forster on the younger Humboldt became a leitmotif of this bond between the two, as evidenced by Harig's assertion that ,[s]einer Bekanntschaft und gemeinsamen Reise mit Georg Forster, diesem großen Vorkämpfer der Idee von 1789 in Deutschland und bedeutenden Naturforscher, verdankte Humboldt sein entscheidendes Bildungserlebnis“ („Alexander von Humboldt" 26). Due to his contextually radical ideas, Forster enjoyed a great deal of attention from East German writers, who regarded him as „eine[r] der wenigen hervorragenden deutschen Gelehrten, die direkt von den jakobinischen Ideen beeinflußt wurden“ (Abusch, „Alexander von Humboldt“ 7), and as ,der hervorragendsten Persönlichkeit der ersten demokratischen Republik auf deutschem Boden in Mainz 1793" (Biermann 17). To be sure, "Forster was a GDR favorite" (Rupke 124). Scurla even pays a touching tribute to the memory of Forster's untimely death in the middle of his biography of Humboldt, stating woefully, ,[d]em Siechtum verfallen, starb einer der edelsten und humansten Söhne unseres Volkes vereinsamt am 10. Januar 1794 in Paris, in seinem Vaterlande verfemt, weil er den Deutschen im Kampf um die Verwirklichung der Menschenrechte weit vorausgeeilt war" (53). It should be noted, however, that no matter how much prestige the East German cultural establishment afforded secular saints such as Goethe, Forster, and Humboldt, they in no way approached the level of reverence reserved for the socialist trinity of Marx, Engels, and Lenin. In the SED's advancement of the wissenschaftliche Weltanschauung and its campaign of subversion through substitution, the discursive power exercised by these three figures remained unmatched throughout the GDR's existence.

\section{Conclusion}

The political and social absence of the GDR over the past quarter century has done little to undermine the perpetuation of certain secular elements extant within the cultural constitution of eastern Germany. The effects of the wissenschaftliche Weltanschauung propagated by the SED and its constituent institutions continue to shape popular and political discourses within the "new" German states in ways that affect the whole of the reunified republic. And these effects do not appear to be diminishing in any appreciable way; rather, the contrary proves true, considering that "many surveys and research projects have revealed that the aftereffects of the anti-religious propaganda and the promotion of an all-embracing notion of science are especially remarkable [...]" (Schmidt-Lux, "Science as Religion" 37). To fully comprehend the impact that such secular influences exercise currently, it becomes necessary to interrogate the initiation of such societal forces, as well as the means by which institutions and cultural actors sustain them. An analysis of the predominant scientistic ideology and the representation and use of figures such as Alexander von Humboldt within the context of the GDR suggests that the success and resilience of an instituted worldview correlates with the adaptability of such a worldview to preexisting frameworks of thought. The fact that the East German cultural establishment successfully pursued its anti-religious agenda through a program of substitution and replacement indicates 
that this gradual conversion to a scientistic worldview, rather than forms of direct confrontation, accounts at least in part for the continuation of secular attitudes in contemporary eastern German culture.

\section{Works Cited}

Abusch, Alexander. „Alexander von Humboldt: Gelehrter, Humanist, Freund der Völker.“ Beilage zu Alexander von Humboldt: Wirkendes Vorbild für Fortschritt und Befreiung der Menschheit. Berlin: Akademie-Verlag, 1969. 1-15.

---. Zum Geleit. Alexander von Humboldt: Wirkendes Vorbild für Fortschritt und Befreiung der Menschheit. Berlin: Akademie-Verlag, 1969. vii-viii.

Biermann, Kurt-Reinhard von. Alexander von Humboldt. Leipzig: Teubner Verlagsgesellschaft, 1982.

---. „War Alexander von Humboldt ein ,Freiherr' (oder ,Baron')?" Schriftenreihe für Geschichte der Naturwissenschaften, Technik und Medizin 26.2 (1989): 1-3.

Froese, Paul and Steven Pfaff. "Explaining a Religious Anomaly: A Historical Analysis of Secularization in Eastern Germany." Journal for the Scientific Study of Religion 44.4 (2005): 397-422.

Gellert, Johannes F. „Alexander von Humboldt: Leben und Werk.“ Alexander von Humboldt: Vorträge und Aufsätze anlässlich der 100. Wiederkehr seines Todestages am 6. Mai 1959. Hrsg. Johannes F. Gellert. Berlin: VEB Deutscher Verlag der Wissenschaften, 1960. 1-10.

Harig, Gerhard. „Alexander von Humboldt, der Naturforscher des deutschen Humanismus.“ Alexander Humboldt: Eine Auswahl. Hrsg. Gerhard Harig. Leipzig: Urania, 1959. 9-38.

---. Vorwort. Alexander Humboldt: Eine Auswahl. Hrsg. Gerhard Harig. Leipzig: Urania, 1959. 6-8.

Hartke, Werner. Vorwort. Alexander von Humboldt: Wirkendes Vorbild für Fortschritt und Befreiung der Menschheit. Berlin: Akademie-Verlag, 1969. xi-xiv.

Humboldt, Alexander von. Kosmos: Entwurf einer physischen Weltbeschreibung. Stuttgart: Verlagshaus Cotta, 1845.

Kossok, Manfred. „Alexander von Humboldt und der historische Ort der Unabhängigkeitsrevolution Lateinamerikas." Alexander von Humboldt: Wirkendes Vorbild für Fortschritt und Befreiung der Menschheit. Berlin: Akademie-Verlag, 1969. 1-26.

Peperkamp, Esther and Malgorzata Rajtar. Introduction. Religion and the Secular in Eastern Germany, 1945 to the Present. Ed. Esther Peperkamp and Malgorzata Rajtar. Leiden: Brill, 2010. 1-18.

Piana, Theo and Horst Schönfelder. Alexander von Humboldt: Ein deutscher Weltreisender und Naturforscher. Berlin: Groszer, 1959.

Rupke, Nicolaas A. Alexander von Humboldt: A Metabiography. Chicago: U of Chicago P, 2005.

Sanke, Heinz. „Alexander von Humboldt: Anläßlich seines 200. Geburtstages.“ Alexander von Humboldt: Wirkendes Vorbild für Fortschritt und Befreiung der Menschheit. Berlin: Akademie-Verlag, 1969. 53-70.

---. „Die gesellschaftlich-geographische Auffassung Alexander von Humboldts.“ Alexander von Humboldt: Vorträge und Aufsätze anlässlich der 100. Wiederkehr seines Todestages am 6. Mai 1959. Hrsg. Johannes F. Gellert. Berlin: VEB Deutscher Verlag der Wissenschaften, 1960. 57-68.

Schäfer, Paul Kanut. Vorwort. Die Besteigung des Chimborazo: Eine Filmexpedition auf Alexander von Humboldts Spuren. Von Paul Kanut Schäfer und Rainer Simon. Köln: VGS Verlagsgesellschaft, 1990. 7-9.

Schmidt, Erwin. „Carl Ritter als Zeitgenosse Alexander von Humboldts.“ Alexander von Humboldt: Vorträge und Aufsätze anlässlich der 100. Wiederkehr seines Todestages am 6. Mai 1959. Hrsg. Johannes F. Gellert. Berlin: VEB Deutscher Verlag der Wissenschaften, 1960. 89-99.

Schmidt-Lux, Thomas. „Das helle Licht der Wissenschaft: Das Urania, der organisierte Szientismus und die ostdeutsche Säkularisierung.“ Geschichte und Gesellschaft 34.1 (2008): 41-72. 
---. "Science as Religion: The Role of Scientism in the Secularization Process in East Germany." Religion and the Secular in Eastern Germany, 1945 to the Present. Ed. Esther Peperkamp and Malgorzata Rajtar. Leiden: Brill, 2010. 19-40.

Schuchardt, Gregor. Fakt, Ideologie, System: Die Geschichte der ostdeutschen Alexander von HumboldtForschung. Stuttgart: Franz Steiner Verlag, 2010.

Scurla, Herbert. Alexander von Humboldt: Eine Biographie. Düsseldorf: Classen, 1982.

Wentker, Hermann. „,Kirchenkampf“ in der DDR: Der Konflikt um die Junge Gemeinde 1950-1953.“ Vierteljahrshefte für Zeitgeschichte 42.1 (1994): 95-127.

Wohlrab-Sahr, Monika, Thomas Schmidt-Lux, and Uta Karstein. "Secularization as Conflict." Social Compass 55.2 (2008): 127-139. 